\title{
Reconnaissance geological and geochemical studies of the Precambrian rocks in Erijiyan Area, Southwestern Nigeria: Implications for mineral exploration
}

\author{
Ayodele, Olusiji Samuel* and Ajigo, Isaac Ominyi \\ Department of Applied Geology, Federal University of Technology, P.M.B. 704, Akure, Nigeria. \\ *Corresponding author. Email: osayodele@futa.edu.ng; samuelayodeleolusiji@yahoo.com
}

Copyright (c) 2019 Ayodele and Ajigo. This article remains permanently open access under the terms of the Creative Commons Attribution License 4.0, which permits unrestricted use, distribution, and reproduction in any medium, provided the original work is properly cited.

Received 15th January, 2019; Accepted 5th February, 2019

\begin{abstract}
Reconnaissance geological and geochemical studies were carried out on the rocks at Erijiyan area to determine its mineral potentials thereby providing a framework for its exploration. Ten fresh rock samples were collected using grid controlled sampling method at a sampling density of one sample per $100 \mathrm{sq} \mathrm{km}^{2}$. The rocks were subsequently prepared for petrographic studies followed by geochemical studies. The petrographic studies involve thin sectioning of the rocks into slides using the standard procedures while the geochemical studies include sample preparation and analyses for its major oxides and trace elements using Inductively Coupled Plasma Spectrophotometry (ICP-MS). The result of the geological mapping revealed three distinct lithologic units such as quartz schists, quartzites and pegmatites with well delineated boundaries, and the major or dominant foliation trend in the NE-SW direction. However, the results of the petrographic analysis showed dominant quartz with minor specks of muscovite while results of geochemical analysis revealed the dominance of $\mathrm{Al}_{2} \mathrm{O}_{3}$ and $\mathrm{SiO}_{2}$ with the quartz having an average percentage composition of $64.73 \% . \mathrm{Al}_{2} \mathrm{O}_{3}$ indicated presence of aluminosilicate-bearing minerals such as feldspar, micas, and feldspathoids. The results of the trace elements analyses revealed that $\mathrm{Mn}$ is the most abundant with an average value of $1065.2 \mathrm{ppm}$ while the average concentrations of other trace elements showed that Ba (1166.9 ppm), Zr (819.4 ppm), Sr (227.9 ppm) and Zn (130.7 ppm). Conclusively, The weathering index shows that the rocks in the study area are moderately weathered implying that the rocks are suitable for geochemical or mineralogical exploration.Considering the geochemical properties of the rocks in the study area, It could be deduced that $\mathrm{Pb}, \mathrm{Cu}$, Zn concentration is indicative of copper-zinc or sulphide mineralization. while. $\mathrm{Pb}, \mathrm{Sr}, \mathrm{Ba}$ and $\mathrm{Zr}$ also indicated the radio active nature of the rocks.
\end{abstract}

Keywords: Erijiyan, geochemistry, mineralization, petrography, statistics, weathering indices.

\section{INTRODUCTION}

A geological map is a synopsis of the distribution of various types of bedrocks that underlie an area, usually produced by the use of a topographic (base) map (a map giving information about the topography and height data of the earth's surface) it is shaded, coloured or design with symbols to show where different rock units occur at or just below the ground surface (Brandon et al., 1998; England and Molnar, 1990; Feng et al., 2018; Ganne et al., 2018). The importance of geological maps cannot be overemphasized as they are planning tools for the economic development of any nation (Agterberg, 1974; Kaufmann and Martin, 2008; Feng et al., 2018). Regional geological maps of southwest Nigeria such as that of Jones and Hockey (1964) have been successfully used in unravelling the geological attributes of a particular locality to identify hidden orebodies or identify potential zones of mineralization. Consequently, there is the need for periodic geological update of local geology and by extension, improvement upon available regional geological maps as this will enhance the understanding of 
the geological resources potential of an area. Geochemistry as a branch of Earth Science applies chemical principles to deepen an understanding of the earth system and systems of other planets (Ganne et al., 2018; Ganne and Feng, 2016).

Geochemists consider the earth as composed of discrete spheres (rocks, fluids and gases) that exchange matter and energy over a range of time scales. An appreciation for rates of reactions and the range of physical conditions responsible for the chemical expressions of each sphere provides the framework to study the co-evolution of the solid earth, its oceans, atmosphere, biosphere, and climate. Analytical instrumentation such as inductively-coupled plasma and stable-isotope mass spectrometers, constitute an indispensable tool in understanding the geochemical make up rocks and other earth materials. A combination of field geological mapping and geochemical analyses will give an insight into the potentials for geological resources that may be available in the study area.

However, this research attempts to investigate the mineral potentials by elucidating the geological and geochemical information that could assist in its exploration.

\section{MATERIALS AND METHODS}

\section{Geological Setting}

The study area covers Erijiyan and its environs which is in Aramoko Local Government, Ekiti State, Nigeria. It is about $50 \mathrm{~km}$ from Ado-Ekiti, with terrain that is gently undulating. The topographic elevation of the area ranges between 530 to $605 \mathrm{~m}$. It lies approximately between latitudes 007036 '0" to $007037^{\prime} 30^{\prime \prime}$ North and longitudes 004059'30" to 0050 1'0" East, and covers an estimated area of $27 \mathrm{~km}^{2}$ (Figure 1). The rocks in the studied area is part of the Basement Complex of Nigeria which forms one of the three major litho-petrologic units that constitute the geology of Nigeria. The Nigerian Basement Complex forms a part of the north-south trending orogenic belt which Grant (1970), Ajibade and Wright (1989) had shown to extend westward into the Benin Republic, Togo and Ghana eastwards into the Cameroon, and northwards into Niger Republic. The crystalline rocks which are exposed today rest on a pre-pan African old basement which is the sialic crust (Turner, 1983). The Nigerian Basement Complex consists of three broad lithological groups: The first is the polymetamorphic migmatite-gneiss complex which is composed largely of migmatite and gneisses of various compositions and amphibolites; also, part of this is the relics of metasedimentary rocks represented by medium to high grade calcareous pelitic and quartzitic rocks occurring within the migmatites and gneisses and they have been described as "Ancient Metasediments" (Oyawoye, 1972). Isotopic ages varying from Liberian to
Pan-African have been obtained for the rocks. The second suit of rocks are the low grade sediment-dominated schists which formed narrow belts in the western half of the country (Figure 2) which has been described as "newer metasediments" (McCurry; 1976) and unmigmatized to slightly migmatised shists (Rahaman, 1976). The schist belts are believed to be relics of a supracrustal cover which was folded into the migmatite gneiss complex (Russ, 1975; McCurry, 1973) and later intruded by Pan-African granitoids.

The third but no less significant group of rocks is the syn to late tectonic granitic rocks which cut both the migmatite gneiss complex and schist belts. The granitoids include rocks ranging in composition from granite to tonalite and charnockite with smaller bodies of syenite and gabbro. Radiometric ages of the granitoids range from 750 to 500 Ma which are within the Pan-African age spectrum. These Pan-African granitoids are called older granites in Nigeria to distinguish them from the Mesozoic tin bearing granite complexes of central Nigeria which are referred to as the Younger granites (Figure 2). The basement complex of Nigeria lies to the east of the West African craton in the region of late Paleozoic orogenesis. It extends westwards and is continuous with the Dahomeyan of the DahomeyTogo-Ghana region. Also, to the east and south, the basement complex is covered by the Mesozoic -Recent Dahomey and Niger coastal basin (Garba, 2003). However, the geology of the South-Western part of Nigeria has been documented by several workers including Odeyemi (1972), Rahaman (1988), Dada and Rahaman (1995) amongst others. In Southwestern Nigeria, the Precambrian suite is represented by the migmatite-gneissquartzite rocks (Feng et al., 2016), the schist belt and PanAfrican intrusives (Older Granites). They cover over 70\% of the entire area (Rahaman 1988).

Within the migmatite-gneiss, banded and melanocratic gneiss are the major rock units. In addition, the metasediments comprise rocks whose earliest and metamorphic fabrics are co-eval with those of the gneisses upon which they lie. Foliated and massive varieties of quartzites are the most dominant meta-sediments occupying the central, southwestern and the north western parts. The regional rock in the mapped area is the migmatite gneiss complex comprising relics of ancient metasedimentary sequences of quartzites quartz schists and pegmatites at strategic locations with well-defined boundaries.

\section{Method}

The methods adopted in carrying out the research include field examination of the outcrops, sampling and geochemical analysis of the rocks. Geological mapping of the study area was carried out at a scale 1:25,000 using grid-controlled sampling method and at a sampling density of one sample per 100sq. The field work entails proper in- 


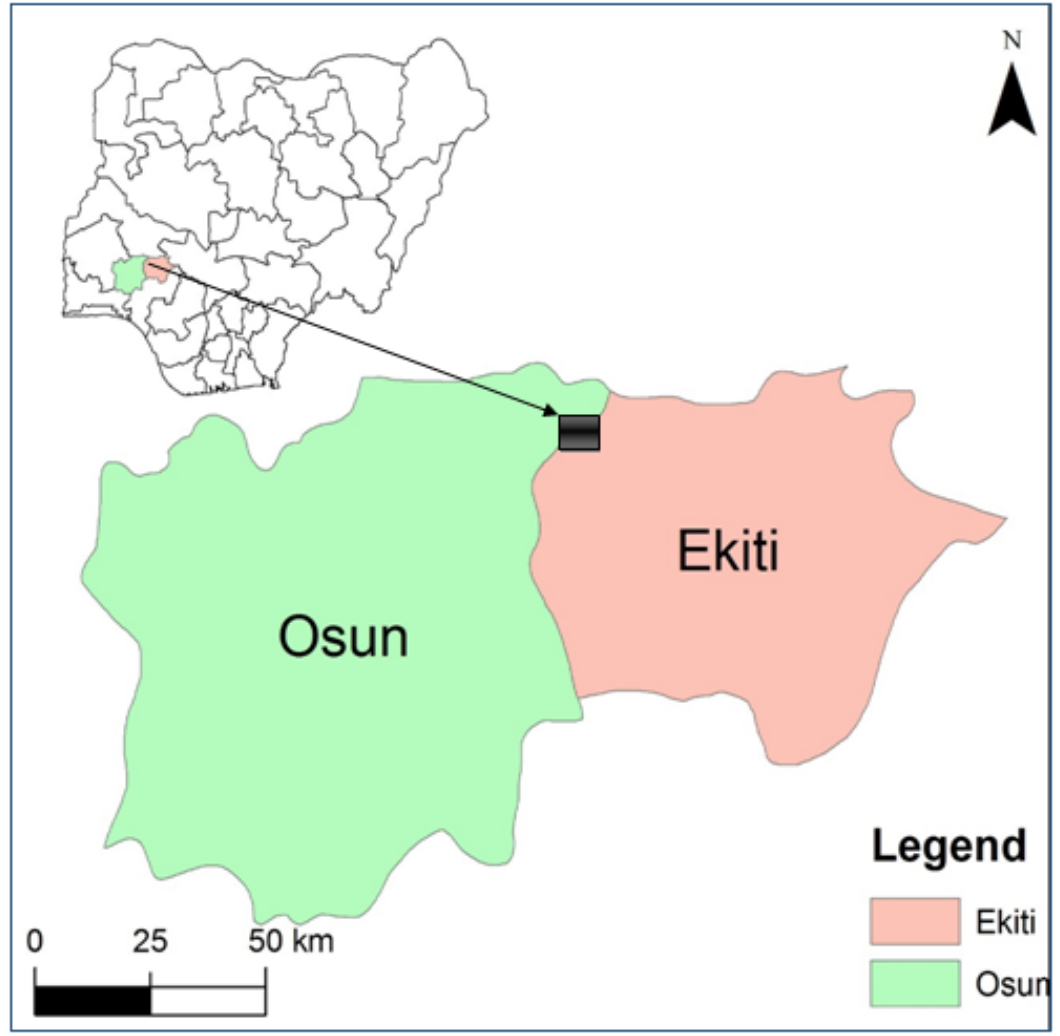

Figure 1. Map of the study area located within Ekiti and Osun States inset: Map of Nigeria showing the study area.

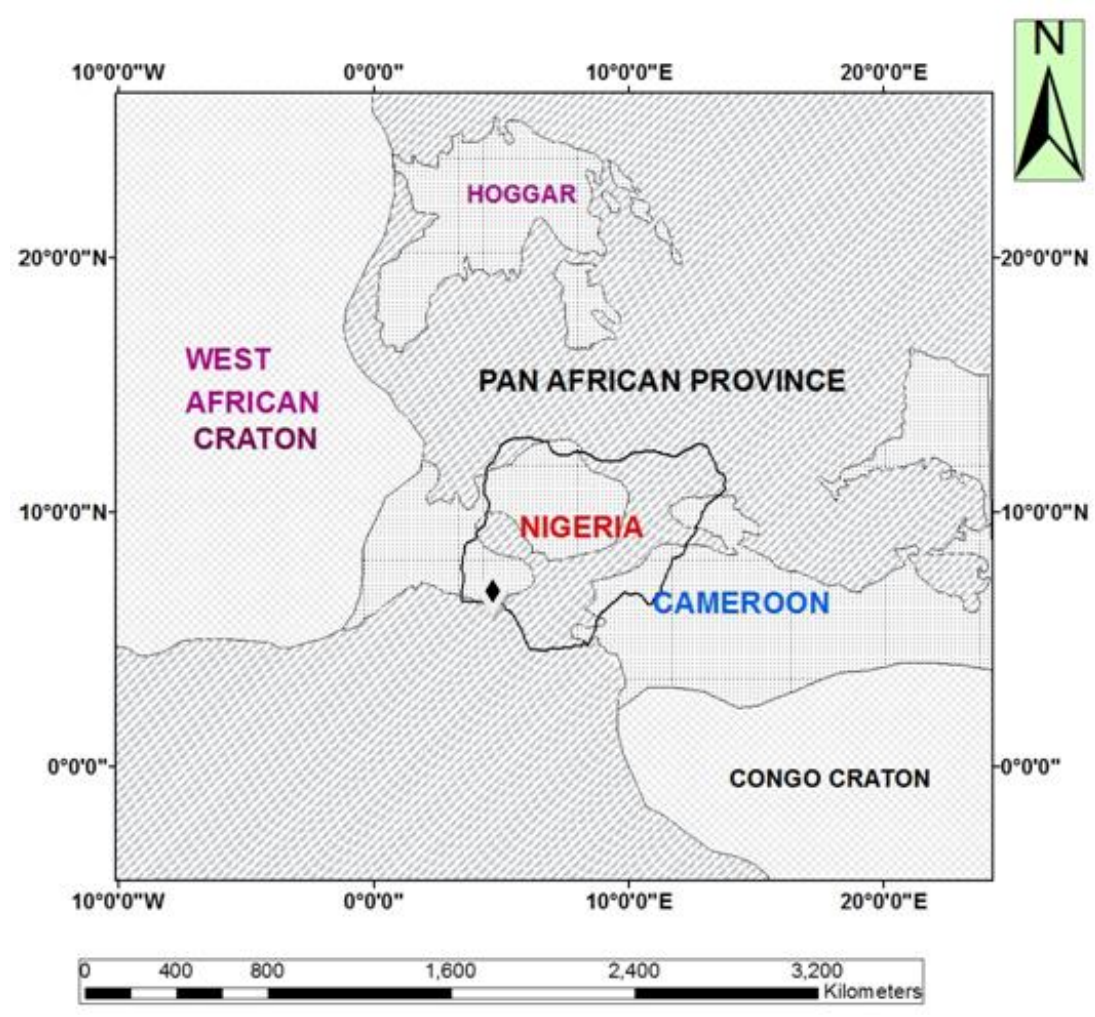

Figure 2. Nigeria within the Pan African Province (Modified after Ajibade, 1988). 
situ observation, identification and systematic description of the outcrops. The geological mapping of the study area was done by traversing the area essentially on foot through existing roads and footpaths with the aid of the global positioning system (GPS) which assisted in determining the accurate geographical positions of the outcrops. Also, detailed study of the structural features in the rocks e.g. folds, joints, dyke, foliation, faults, lineations etc and their orientations were measured and recorded in the field notebook. Ten fresh rock samples were selected from the bulk samples and prepared for thin section studies under transmitted light as well as geochemical analyses (Major Oxides and Trace elements determinations).

The samples were crushed and packed at the geochemical laboratory of the Department of Geology, Obafemi Awolowo University (OAU) Ile-lfe, Nigeria. Subsequent physical and chemical treatment such as pulverizing to 200 mesh (85\%) and chemical analysis were carried out in ACME Analytical Laboratories East Vancouver, Canada using Inductively Coupled Plasma Mass Spectrometer (ICP-MS) and Inductively Coupled Plasma Emission Spectrometer (ICP-ES). Total abundances of the major oxides were measured using 0.5 $\mathrm{g}$ of sample pulp, analyzed by ICP-Emission Spectrometry following a Lithium metaborate/tetraborate (LIBO2/LI2B4O7) fusion and dilute nitric digestion (Watts and Johnson, 2012).

The trace elements which are basically base and precious metals were measured using $0.5 \mathrm{~g}$ of sample pulp digested in Aqua Regia and analyzed by ICP-Mass Spectrometry. The analytical procedure involved addition of $5 \mathrm{ml}$ each of perchloric acid (HCL04), trioxonitrate (V) $\mathrm{HNO}_{3}$ and $15 \mathrm{ml}$ hydrofluoric acid (HF) to $0.5 \mathrm{~g}$ of sample, the solution was stirred properly and allowed to evaporate to dryness after it was warmed at a low temperature for some hours. Four (4) $\mathrm{ml}$ of hydrochloric acid (HCL) was then added to the cooled solution and warmed to dissolve the salts. The solution was cooled; and then diluted to 50 $\mathrm{ml}$ with distilled water. The solution was then introduced into the ICP torch as aqueous - aerosol. The emitted light by the ions in the ICP was converted to an electrical signal by a photo multiplier in the spectrometer. The intensity of the electrical signal produced by emitted light from the ions were compared to a standard (a previously measured intensity of a known concentration of the elements) and the concentrations were then computed. Analytical precisions vary from 0.1 to $0.04 \%$ for major elements.

\section{RESULTS AND DISCUSSION}

\section{Field occurrences}

The major rock types are the quartzites and pegmatites with minor occurrences of quartz schists (Figure 3). They are well exposed outcrops and flat lying. They were also seen cutting across river and stream channels as well as road cuts. Quartzite is the dominant rock type in the study area, occupying about $60 \%$ of the entire area. It is massive, highly fractured and jointed with their orientations trending N-S. The quartzite mapped in Aramoko road are ferruginized types. The outcrop is low-lying but hilly in other areas, they are also intercalated with bands of quartz schist at the western part of the studied area. The bands are weaker and less fractured than the pure quartzite. The strike of the quartz schists is $158^{\circ}$ and the dip is $30^{\circ} \mathrm{E}$. The pegmatite bodies are confined to the north-eastern part of the studied area and they have an average strike of $45^{\circ}$ in the NE-SW direction. They are exposed along stream channels and road cuts. These pegmatites are complex, coarse grained and are highly weathered as a result of which fresh samples are hardly available.

\section{Structures}

These are imprints left on the outcrops as a result of the different episodes of deformation experienced by the outcrops over time. The structural data obtained in the study area are basically from field studies and observations. The prominent structural features manifested by the rocks are joints and fractures. It is a wellknown fact that some structures such as folds, faults and fractures control ore deposition and mineralization, certain fractures (lineaments) like the NE-SW types have been suggested by Wright (1976) to have connections with oceanic fracture zones and may harbour mineralization. In other cases, favourable mineral locations may occur where lineaments intersect or where they are associated with suitable geological conditions. The joints are mostly orientated in NE-SW direction (Figure 6). These fractures and joints are products of brittle deformation accompanied by low temperature and high strain rate. The joints are orientated in different ways where the direction of the maximum stress may be vertical, horizontal and inclined.

\section{Petrography}

The petrographic study revealed that the dominant mineral in the quartzite is dominantly quartz and its composition vary across the thin sections viewed under the Petrological microscope. For instance, at Aramoko road, the quartzite contains quartz with altered feldspar (sericites) and there are presence of a fine grained quartz vein which is set in the matrix of quartz (Figure 5a). Also at Ikogosi road, the quartz phenocrysts are set in a fine matrix of the quartz (Figure $5 b$ ) whereas, other slides of quartzite and quartz schists are having quartz grains with inclusions of short fibrous-like muscovite (Figure 5c). Also, there are specks of muscovite mineral in other slides of quartzite that were viewed. The specks of muscovite are randomly spaced and the planar orientations of the specs are fairly pronounced (Figure $5 \mathrm{~d}$ ). The geologic and cross-section map of the studied area is presented (Figure 4). 

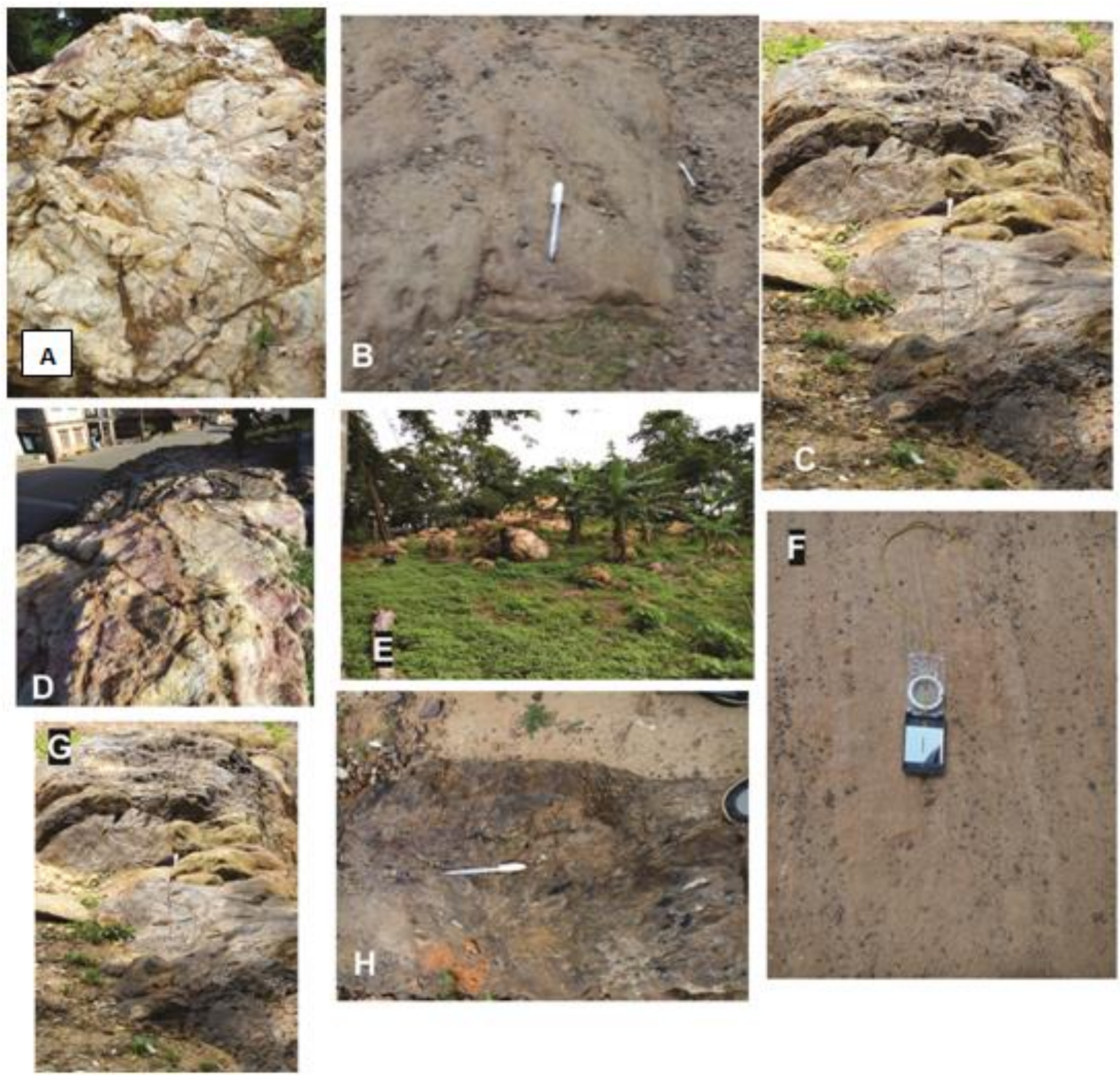

Figure 3. Field Photographs of quartzite and quartz schist units (a) Quartzite with some fractures (b) a portion showing quartz schist (c) \& (d) section through portions of Jointed and weathered Quartzite (e) Extensie exposure of Quartzite at Oke Agbara (f)Road cut Showing quartz Schist around Baptist (g) Low lying outcrop of quartzite along Erinjiyan-Ikogosi Road (h) offshoot of quartzite in the quartzite around iwaro

\section{Geochemistry}

The result of the major oxides of the rocks is presented in Table.1. It displayed a range of values for the dominant major oxides in the system such that $\mathrm{SiO}_{2}$ (55.56 to $78.4 \%$ ), $\mathrm{Al}_{2} \mathrm{O}_{3}(4.7$ to $16.33 \%), \mathrm{Fe}_{2} \mathrm{O}_{3}(0.64$ to $9.62 \%)$, $\mathrm{CaO}(0.62$ to $4.28 \%), \mathrm{MgO}(0.02$ to $20.51 \%)$ and $\mathrm{K}_{2} \mathrm{O}(2.01$ to $6.05 \%)$. The overall results showed that $\mathrm{SiO}_{2}$ is the most abundant mineral in all the rock types with the highest percentage present in the quartzite $(78.4 \%)$ and the lowest concentration (55.56\%). $\mathrm{TiO}_{2}$ and $\mathrm{Cr}_{2} \mathrm{O}_{7}$ are the least abundant mineral with an average composition of less than $1 \%$ in all the rock samples.

The ferromagnesian compounds $\left(\mathrm{Fe}_{2} \mathrm{O}_{3}\right.$ and $\mathrm{MgO}$ ) have varying abundances in the rock samples. $\mathrm{Fe}_{2} \mathrm{O}_{3}$ value is higher in the quartzite at location 28 , having $9.62 \%$ along Aramoko road thereby confirming the ferruginous nature of the quartzites, while the lowest percentage is found in the quartzite at location 1 (0.64\%). $\mathrm{MgO}$ concentration is highest in the quartzite at Location 24 around Kootu with a 

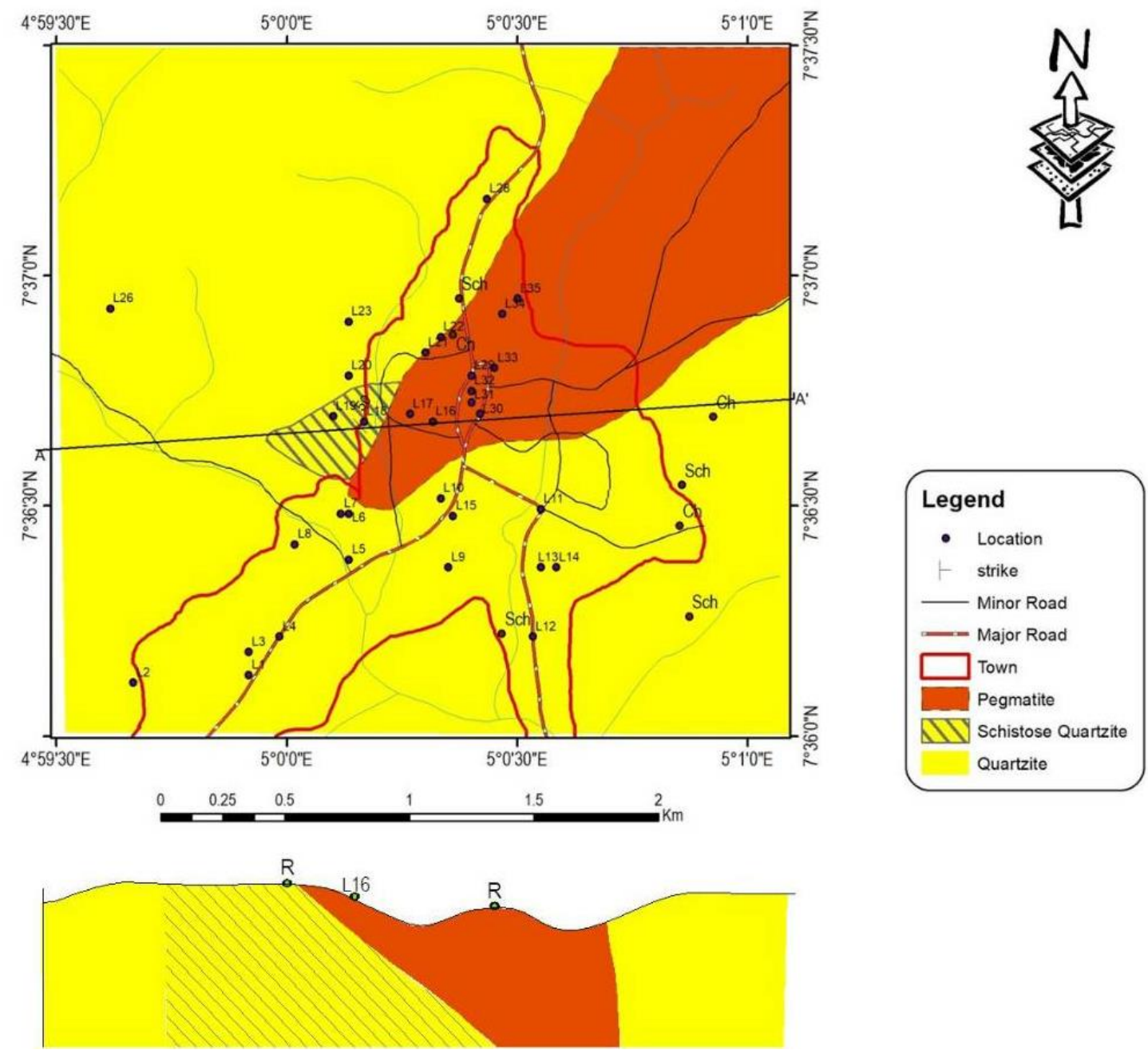

Figure 4. Geologic and Cross-section map of the study area.

percentage concentration of $20.51 \%$ while the pegmatite has the lower value of $\mathrm{MgO}(0.24 \%)$ (Table 1$)$. In addition, $\mathrm{CaO}$ and $\mathrm{MgO}$ concentrations are diverse in some locations, thereby indicating the basic nature and the underlying lithology of some of the rocks in the studied area (Boyle et al., 1996). The concentration of $\mathrm{CaO}$ being slightly higher than $\mathrm{MgO}$ on the average could also be as a result of remobilization of pre-existing minerals in the rock (Table 1 ). In addition, they exhibited the same trend across the study area which could also be due to the nature and composition of the parent material prior to metamorphism (Beus and Grigorian, 1977). This assertion could be responsible for the pattern of variations across the major oxides as well the plots of major oxides against the investigated locations (Figures 7 and 8).

The results of the trace elements of the rocks is presented in Table 2. However, the result revealed that Barium (Ba) is the most abundant trace elements in the quartzites of the study area. $(\mathrm{Ba})$ has the range of 8 to $2367 \mathrm{ppm}$ with an average value of $1667 \mathrm{ppm}$. It is exceptionally high because the study area is intruded by older granitoids. This unusual characteristic may be attributed to the original initial composition of the magma that form the granite or dissolution of the country rocks to which the magma was injected. It may also be an indication that the quartzite in the study area harbors some radioactive minerals. Quartzite has the highest concentration of $\mathrm{Ba}(2367 \mathrm{ppm})$ while pegmatite has a relatively lower concentration of $\mathrm{Ba}(1706 \mathrm{ppm})$. The highest concentration of $\mathrm{Pb}$ is found at Ago-Olopa, location 23 while $\mathrm{Zn}$ has the highest concentration in the pegmatite at location 33, having $235 \mathrm{ppm}$. There is higher concentration of $\mathrm{Zn}$ in all the rock samples compared with $\mathrm{Pb}$. Chromium content ranges from 5 to 1310ppm which is quite high and which may be hosted either by the quartzite or pegmatites in the studied area. The pegmatite also contains fairly equal amounts of $\mathrm{Cu}$ and $\mathrm{Y}$ compared to the quartzite. The concentration of Gold is very low $(<0.1)$ which indicates that the analyzed samples have showings of gold mineralization. However, no mineral of economic 

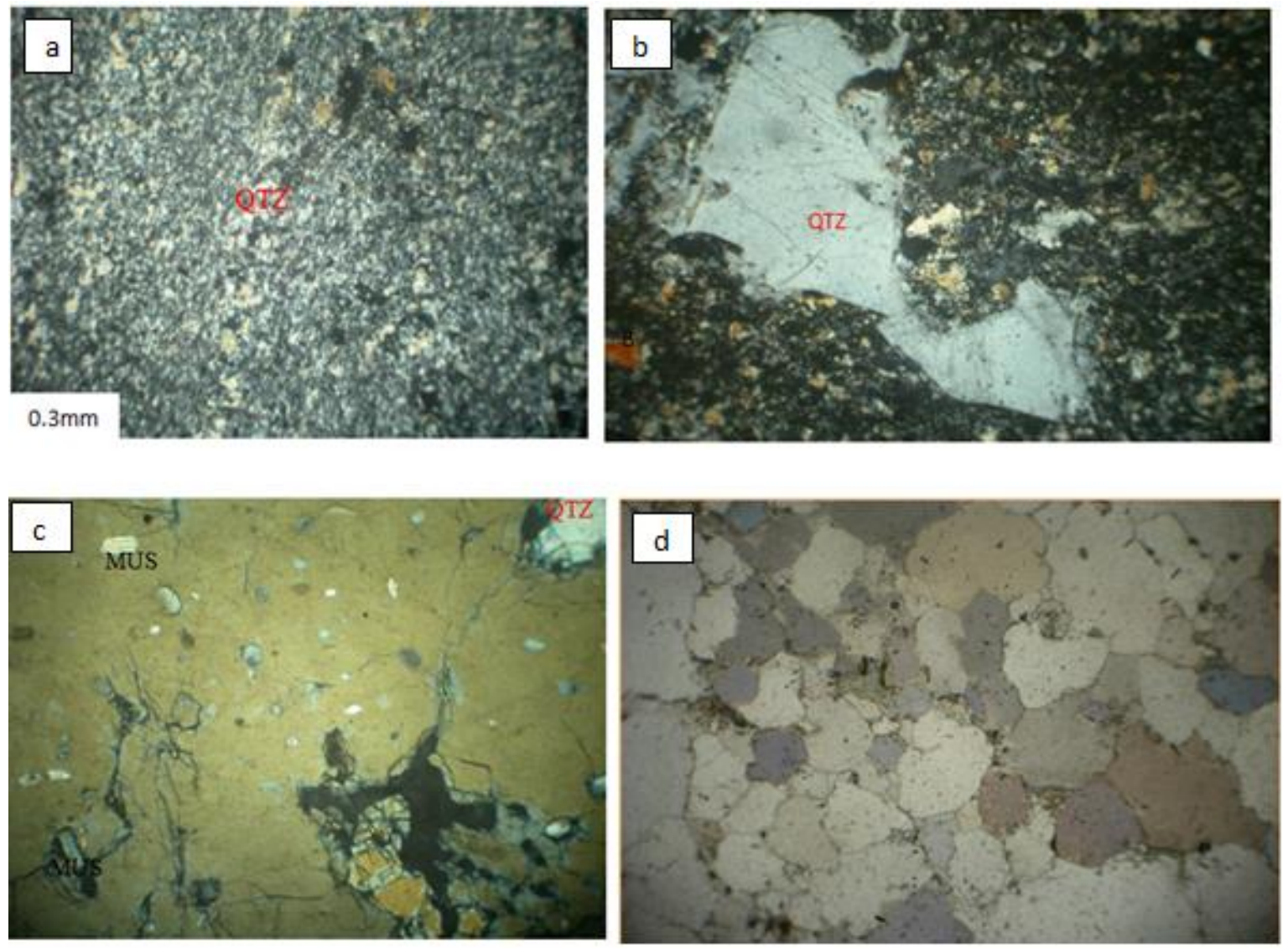

Figure 5. (a) Fine quartz vein which is set in ground mass of fine grained qaurtz and altered feldspars (sericites), (b) Quartz phenocryst set in fine matrix in a pyroclastic texture (c) quartz grain with inclusion of muscovite (short fibrous);(d) mainly quartz with specks of muscovite.

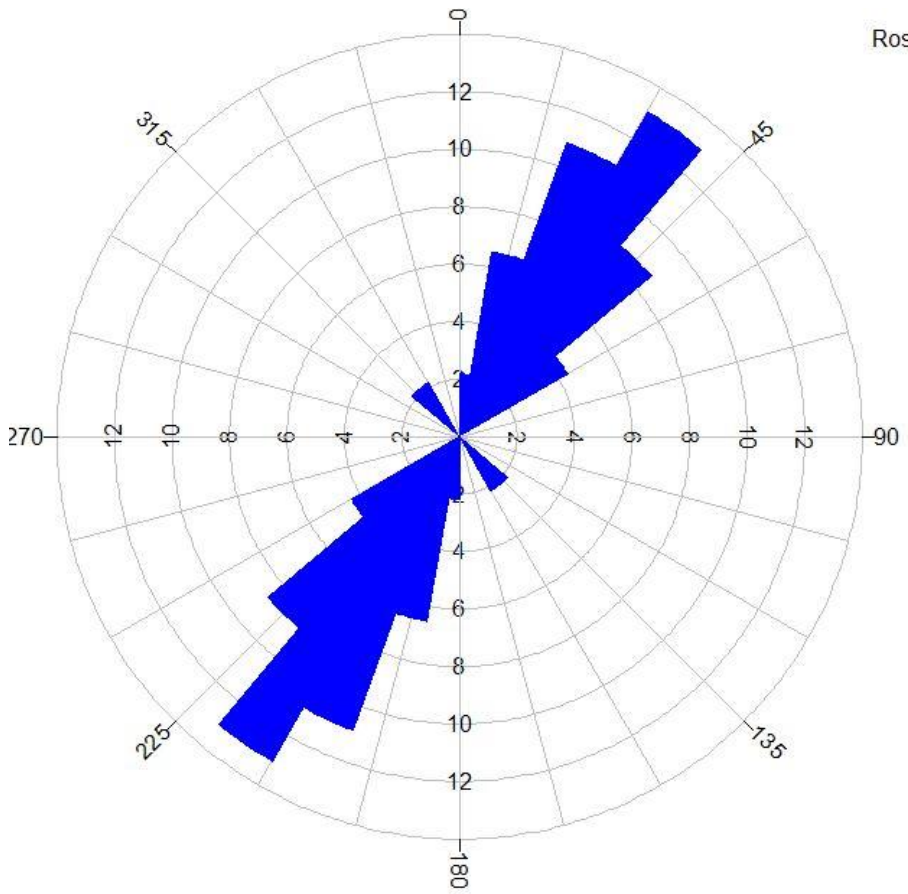

Rose Diagram

\section{Statistical Summary}

Calculation Method: Frequency Class Interval: 10.0 Degrees Azimuth Filtering: Deactivated Data Type: Bidirectional Population: 23

Total Length of All Lineations: 46.0

Maximum Bin Population: 6.0

Mean Bin Population: 2.88

Standard Deviation of Bin Population: 1.89

Maximum Bin Population (\%): 13.04

Mean Bin Population (\%): 6.25

Standard Deviation of Bin Population (\%): 4.12

Maximum Bin Length: 6.0

Mean Bin Length: 2.88

Standard Deviation of Bin Lengths: 1.89

Maximum Bin Length (\%): 13.04

Mean Bin Length (\%): 6.25

Standard Deviation of Bin Lengths (\%): 4.12

Vector Mean: 27.7 Degrees

207.7 Degrees

Confidence Interval: 17.5 Degrees

( 95 Percent )

R-mag: 0.75

Figure 6. Rose Diagram plot showing the trend of the mapped joints. It is seen that the dominant trend direction is NE-SW. 
Table 1. Major oxide Geochemistry (\%).

\begin{tabular}{|c|c|c|c|c|c|c|c|c|c|c|c|c|}
\hline $\mathrm{S} / \mathrm{N}$ & Sample ID & $\mathrm{SiO}_{2}$ & $\mathrm{Al}_{2} \mathrm{O} 3$ & $\mathrm{Fe}_{2} \mathrm{O}_{3}$ & $\mathrm{MgO}$ & $\mathrm{CaO}$ & $\mathrm{Na}_{2} \mathrm{O}$ & $\mathrm{K}_{2} \mathrm{O}$ & $\mathrm{TiO}_{2}$ & $\mathrm{P}_{2} \mathrm{O}_{5}$ & MnO & $\mathrm{Cr}_{2} \mathrm{O}_{3}$ \\
\hline 1 & $\begin{array}{l}\text { IKOGOSI ROAD } \\
\text { L5(Qzt) }\end{array}$ & 73.76 & 14.57 & 0.64 & 0.02 & 0.62 & 3.77 & 6.05 & 0.01 & 0.03 & 0.09 & $<0.002$ \\
\hline 2 & $\begin{array}{l}\text { IWARO NORTH } \\
\text { L7(Qzt) }\end{array}$ & 65.6 & 12.7 & 5.78 & 1.18 & 2.92 & 2.83 & 4.88 & 0.51 & 0.16 & 0.09 & $<0.002$ \\
\hline 3 & $\begin{array}{l}\text { OKE-AGBARA } \\
\text { L10(Qzt) }\end{array}$ & 66.71 & 15.74 & 4.65 & 1.34 & 3.64 & 4.1 & 2.01 & 0.69 & 0.19 & 0.07 & $<0.002$ \\
\hline 4 & BAPTIST L16(Qzt) & 78.4 & 10.59 & 2.2 & 0.3 & 0.63 & 1.82 & 5.05 & 0.19 & 0.05 & 0.02 & $<0.002$ \\
\hline 5 & AAFIN L17(Peg) & 65.93 & 15.38 & 5.8 & 0.24 & 3.82 & 3 & 4.33 & 0.59 & 0.21 & 0.08 & $<0.002$ \\
\hline 6 & $\begin{array}{l}\text { AGO-OLOPA } \\
\text { L23(Qzt) }\end{array}$ & 62.68 & 13.39 & 7.29 & 2.21 & 3.60 & 1.57 & 4.39 & 1.00 & 0.15 & 0.16 & 0.006 \\
\hline 7 & $\begin{array}{l}\text { COMMUNITY- } \\
\text { COURT L24(Qzt) }\end{array}$ & 55.56 & 4.7 & 5.17 & 20.51 & 1.03 & 1.04 & 6.2 & 0.29 & 0.02 & 0.04 & 0.299 \\
\hline 8 & $\begin{array}{l}\text { ARAMOKO ROAD } \\
\text { L28(Qzt) }\end{array}$ & 59.69 & 14.43 & 9.62 & 2.58 & 3.88 & 1.91 & 2.44 & 1.25 & 0.23 & 0.38 & 0.034 \\
\hline 9 & EFON L30(Qzt) & 60.69 & 13.93 & 8.73 & 2.78 & 2.18 & 2.21 & 2.64 & 1.35 & 0.13 & 0.37 & 0.036 \\
\hline 10 & ST.PAUL 33(Peg) & 58.23 & 16.33 & 9.28 & 0.52 & 4.28 & 2.41 & 3.75 & 1.11 & 0.48 & 0.11 & 0.064 \\
\hline
\end{tabular}

Table 2. Trace elements Geochemistry of the rocks (ppm).

\begin{tabular}{llllllllllll}
\hline $\mathbf{S} / \mathbf{N}$ & Sample ID & $\mathbf{B a}$ & $\mathbf{N i}$ & $\mathbf{S r}$ & $\mathbf{Z r}$ & $\mathbf{Y}$ & $\mathbf{N b}$ & $\mathbf{S c}$ & $\mathbf{M o}$ & $\mathbf{C u}$ & $\mathbf{P b}$ \\
\hline 1 & Ikogosi Road L5 & 476 & 1.9 & 145 & 25 & 3 & 19 & $<1$ & 0.4 & 6.9 & 24.6 \\
2 & Iwaro North L7 & 2367 & 2 & 249 & 855 & 65 & 33 & 17 & 1.2 & 19.5 & 31.1 \\
3 & Oke-Agbara L10 & 383 & 8.5 & 437 & 300 & 29 & 24 & 3 & 2.4 & 22.3 & 23.3 \\
4 & Baptist L16 & 548 & 2.1 & 63 & 375 & 51 & 7 & 4 & 0.9 & 12.5 & 39.4 \\
5 & Aafin L17 & 1724 & 1.9 & 386 & 1043 & 60 & 28 & 12 & 1.1 & 22.5 & 28.2 \\
6 & Ago-Olopa L23 & 1865 & 13.7 & 151 & 3532 & 70 & 36 & 12 & 2.3 & 27.3 & 63.6 \\
7 & Community- Court L24 & 8 & 1637.9 & 2 & $<5$ & $<3$ & 14 & 4 & $<0.1$ & 6.2 & 0.9 \\
8 & Aramoko Road L28 & 1331 & 49.0 & 266 & 626 & 39 & 26 & 14 & 1.2 & 51.8 & 46.6 \\
9 & Efon L30 & 1261 & 44.0 & 226 & 593 & 48 & 16 & 15 & 1.1 & 50.8 & 47.1 \\
10 & St.Paul 33 & 1706 & 8.6 & 354 & 840 & 77 & 44 & 20 & 3.8 & 76.3 & 33.0 \\
\hline
\end{tabular}

Table 2. contd.

\begin{tabular}{lllllllllllll}
\hline S/N & Sample ID & Zn & Co & As & $\mathbf{U}$ & $\mathbf{A u}$ & $\mathbf{T h}$ & $\mathbf{S r}$ & $\mathbf{M n}$ & $\mathbf{C r}$ & $\mathbf{F e}$ & $\mathbf{V}$ \\
\hline 1 & Ikogosi Road L5 & 7 & 0.3 & 2 & 2.6 & $<0.1$ & 1.5 & 139 & 662 & 6 & 0.41 & 4 \\
2 & Iwaro North L7 & 156 & 3.1 & 1 & 0.8 & $<0.1$ & 11.8 & 249 & 674 & 11 & 4.04 & 75 \\
3 & Oke-Agbara L10 & 69 & 11.1 & 3 & 6.3 & $<0.1$ & 30.5 & 447 & 571 & 8 & 3.17 & 3 \\
4 & Baptist L16 & 72 & 1.4 & 2 & 3.7 & $<0.1$ & 50.1 & 58 & 148 & 6 & 1.58 & 4 \\
5 & Aafin L17 & 125 & 4.4 & 2 & 1.2 & $<0.1$ & 12.3 & 388 & 593 & 45 & 3.84 & 55 \\
6 & Ago-Olopa L23 & 165 & 23.2 & 3 & 4.3 & $<0.1$ & 26.2 & 153 & 1447 & 1310 & 5.78 & 31 \\
7 & Community-Court L24 & 75 & 65.2 & 2 & 1.1 & $<0.1$ & $<0.1$ & 2 & 299 & 140 & 3.44 & 125 \\
8 & Aramoko Road L28 & 201 & 62.6 & 3 & 2.7 & $<0.1$ & 15.9 & 287 & 2784 & 151 & 6.37 & 121 \\
9 & Efon L30 & 202 & 63.3 & 3 & 2.5 & $<0.1$ & 13.9 & 31 & 2682 & 30 & 6.31 & 17 \\
10 & St.Paul 33 & 235 & 10.5 & 3 & 3.3 & $<0.1$ & 39.0 & 372 & 792 & 12 & 6.27 & 22 \\
\hline
\end{tabular}

importance has been reported in the area lately, but the pegmatites and quartzites in the study area could serve as a potential source of mineralization, especially metallic minerals such as $\mathrm{Au}, \mathrm{Cu}, \mathrm{Cr}$ and Pt. The schistose quartzite in the study area could be chemically comparable to the metasediments of the south western Nigeria (Freeth, 1971, Rahaman and Ocan (1978) and those of Okemesi area (Ayodele et al., 2017; Akanmu et al., 2019). 


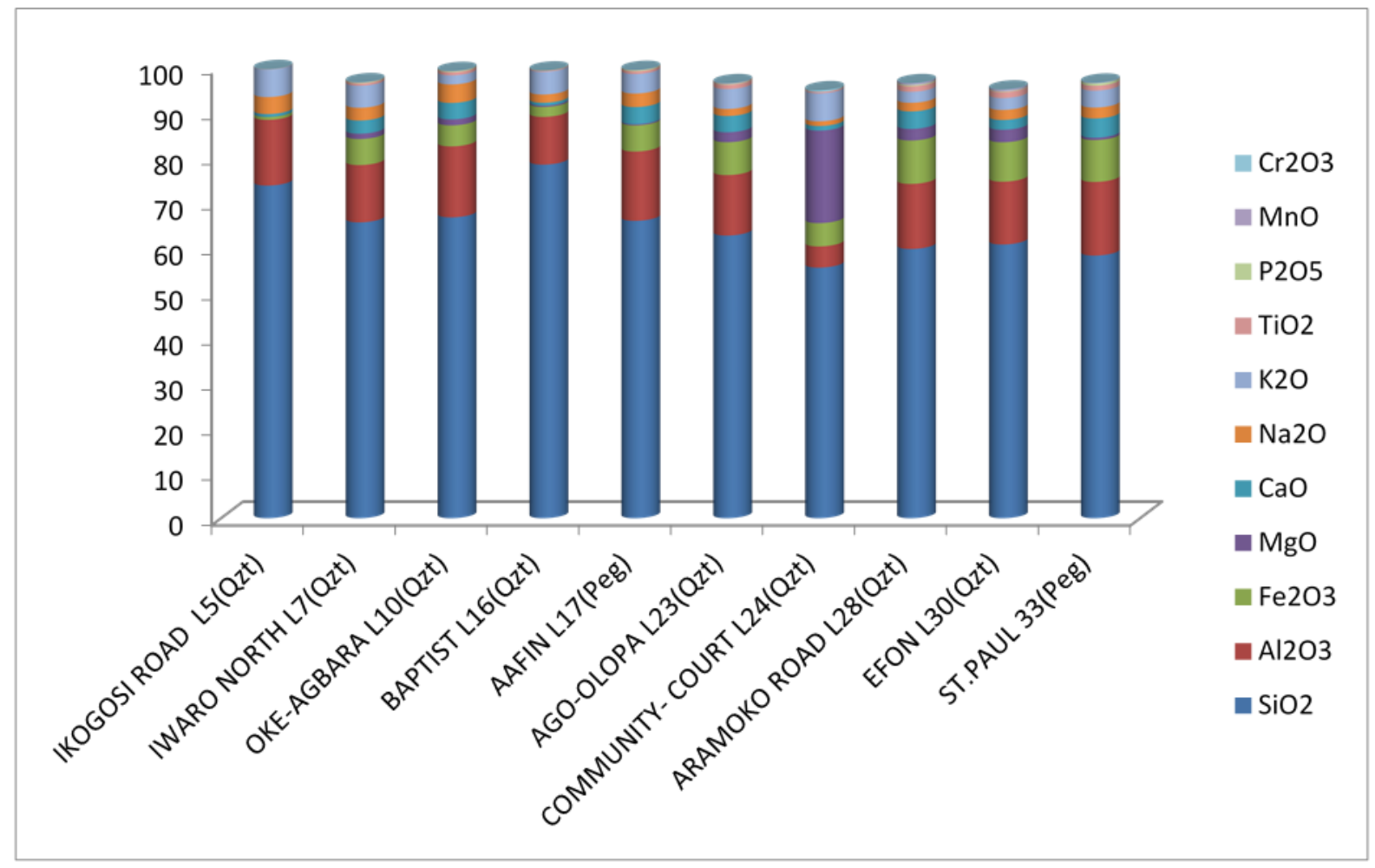

Figure 7. Variation in major oxides.
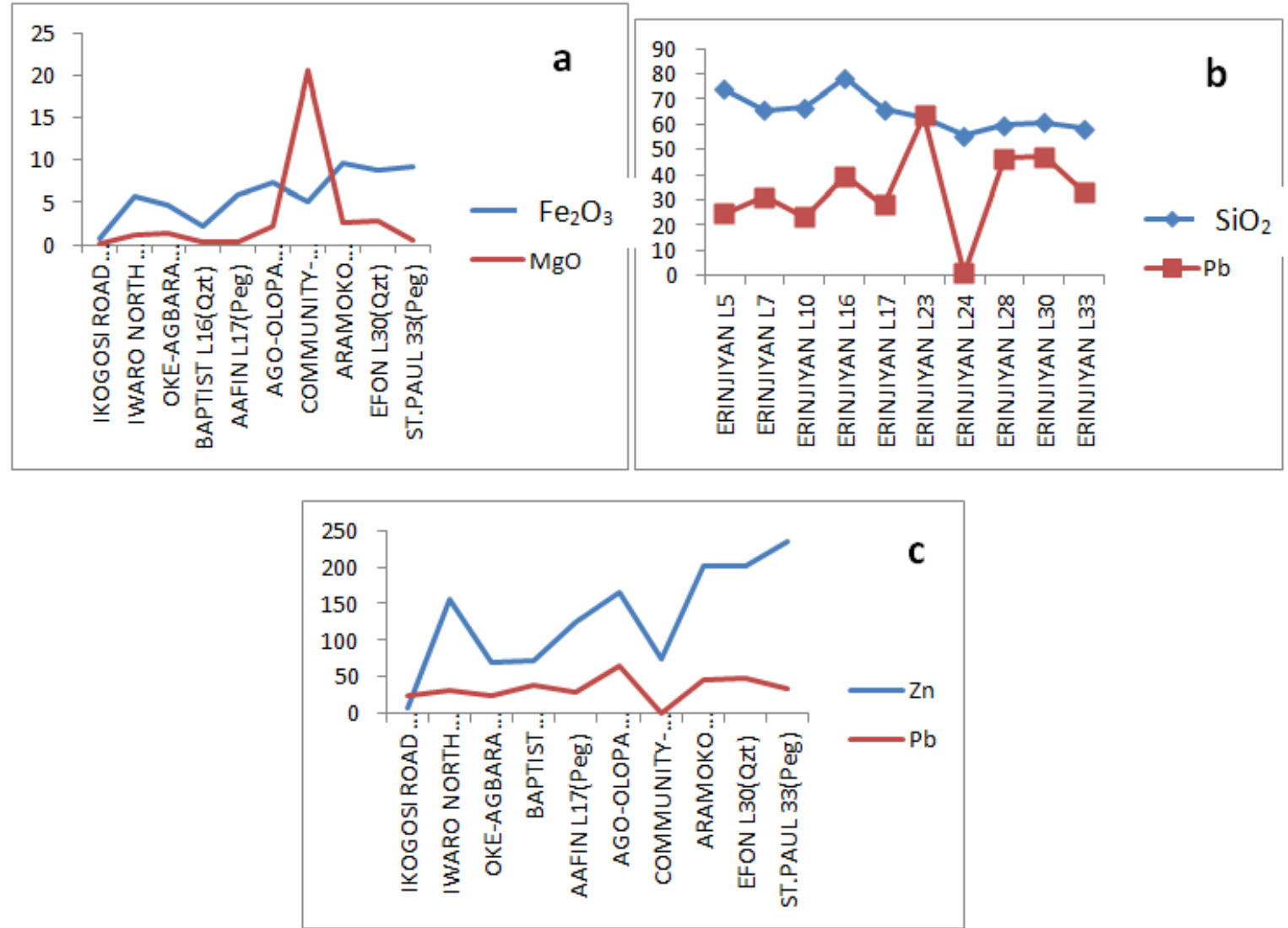

Figure 8. Plot of variations against locations in (a) $\mathrm{MgO}$ against $\mathrm{Fe}_{2} \mathrm{O}_{3}$; (b) $\mathrm{SiO}_{2}$ against $\mathrm{Pb}$; (c) $\mathrm{Zn}$ against $\mathrm{Pb}$. 

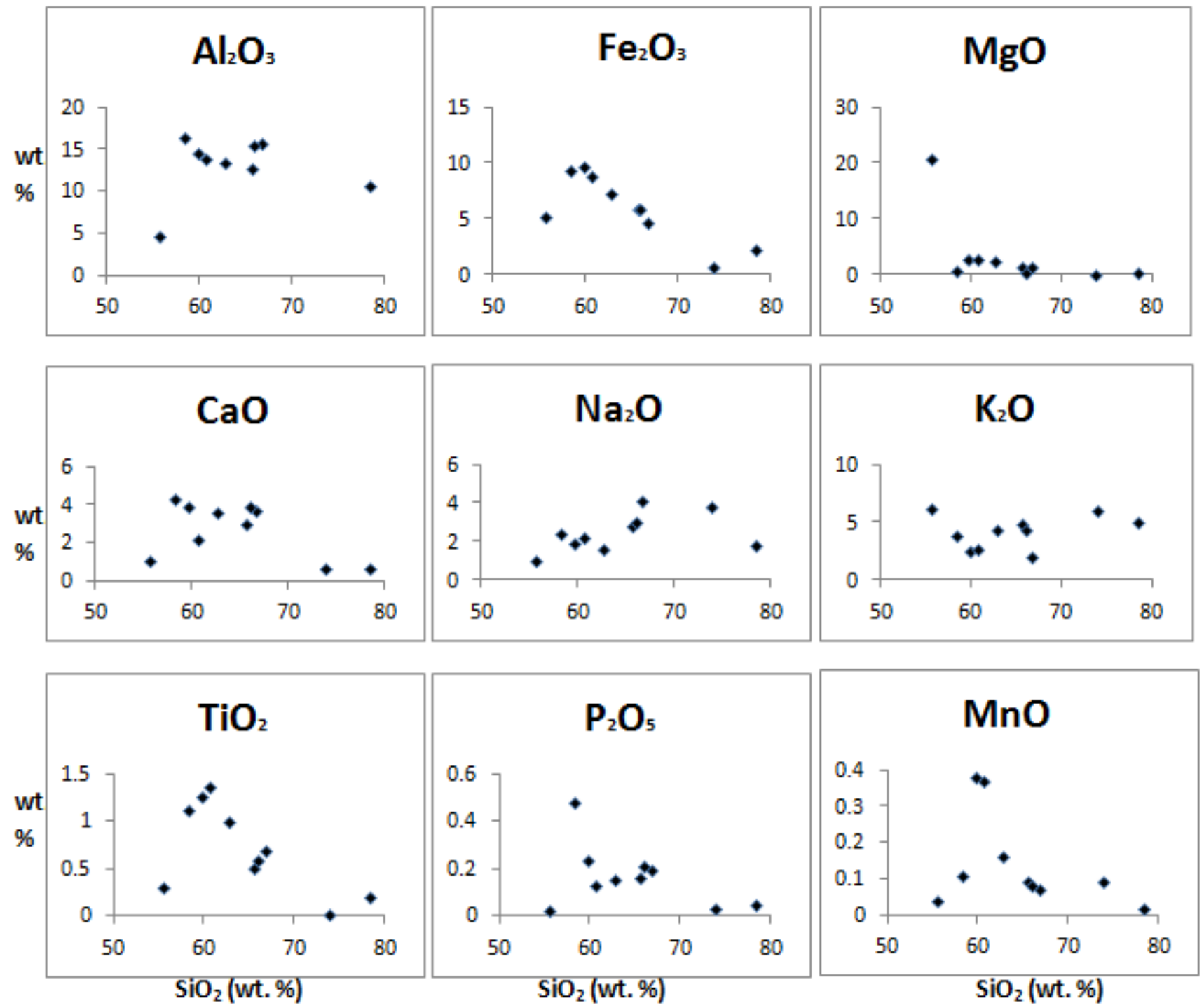

Figure 9. Correlation of the major oxides with $\mathrm{SiO}_{2}$.

\section{Descriptive statistics}

\section{Correlation}

There is no relationship between the major oxides such as $\mathrm{Al}_{2} \mathrm{O}_{3}, \mathrm{Fe}_{2} \mathrm{O}_{3}, \mathrm{MgO}, \mathrm{CaO}, \mathrm{Na}_{2} \mathrm{O}, \mathrm{K} 2 \mathrm{O}, \mathrm{TiO}_{2}, \mathrm{P}_{2} \mathrm{O}_{5}$ and $\mathrm{MnO}$ with $\mathrm{SiO}_{2}$ in the geochemical system due to the heterogeneous nature of the magma (Figure 9). However, the correlation among the trace metals showed abundance of metals such as $\mathrm{Cu}, \mathrm{Pb}, \mathrm{Zn}, \mathrm{Mn}$ and $\mathrm{As}$ as being positively correlated with most metals while $\mathrm{Fe}$ is negatively correlated with other metals except Co (Table 5).

\section{Multivariate Statistics and indications}

The multivariate statistical tables of the dominant metals are presented in Tables 3 and 4 respectively. As usual, Ba,
$\mathrm{Cu}, \mathrm{Pb}, \mathrm{Zn}, \mathrm{Mn}, \mathrm{Fe}$ and $\mathrm{Cr}$ account for the highest mean concentration in the quartzite and pegmatites (Tables 3 and 4). The concentration of As being a pathfinder for gold indicated showings of gold mineralization in the quartz schist or pegmatites even though it is $<0.1 \%$ which is very negligible. Nevertheless, the negligibility of Au still signifies showings of the mineral which are of uneconomic concentration except if upgraded by detailed geochemical prospecting and exploration for gold in the studied area. The relative abundance of $\mathrm{Fe}$ in chemical composition of the quartzites also confirmed the ferruginous nature of the quartzites (Tables 1 and 3) while the occurrence of $\mathrm{Cu}, \mathrm{Pb}$ and $\mathrm{Zn}$ could indicate possible sulphide mineralization.

\section{Weathering indices}

The weathering index is a measure of the intensity of 
Table 3. Multivariate statistics for trace elements in rock samples.

\begin{tabular}{|c|c|c|c|c|c|c|}
\hline \multirow{2}{*}{ Elements } & \multicolumn{5}{|c|}{ Statistic } & \multirow{2}{*}{ Interpretation } \\
\hline & $\mathbf{N}$ & Minimum & Maximum & Mean & Std. Deviation & \\
\hline $\mathrm{Ba}$ & 10 & 8.00 & 2367.00 & 1166.9000 & 773.32506 & \multirow[t]{6}{*}{$\begin{array}{l}\text { Highest conc. Suggests } \\
\text { radioactive environment. }\end{array}$} \\
\hline $\mathrm{Cu}$ & 10 & 6.20 & 76.30 & 29.6100 & 22.82647 & \\
\hline $\mathrm{Pb}$ & 10 & 0.90 & 63.60 & 33.7800 & 16.92045 & \\
\hline $\mathrm{Zn}$ & 10 & 7.00 & 235.00 & 130.7000 & 73.34098 & \\
\hline $\mathrm{Ag}$ & 10 & 0.00 & 0.00 & 0.0000 & 0.00000 & \\
\hline Co & 10 & 0.30 & 65.20 & 24.5100 & 27.83285 & \\
\hline $\mathrm{Mn}$ & 10 & 148.00 & 2784.00 & 1065.2000 & 942.80065 & \multirow[t]{6}{*}{$\begin{array}{l}\text { Establishes the tropical nature } \\
\text { of the environment }\end{array}$} \\
\hline $\mathrm{Fe}$ & 10 & 5.00 & 1310.00 & 171.2000 & 403.95456 & \\
\hline AS & 10 & 0.30 & 65.20 & 24.5100 & 27.83285 & \\
\hline V & 10 & 0.00 & 125.00 & 43.5000 & 48.63069 & \\
\hline $\mathrm{Cr}$ & 10 & 5.00 & 1310.00 & 171.2000 & 403.95456 & \\
\hline $\begin{array}{l}\text { Valid N } \\
\text { (listwise) }\end{array}$ & 10 & & & & & \\
\hline
\end{tabular}

Table 4. Descriptive Statistics for trace elements.

\begin{tabular}{lccc}
\hline Elements & Mean & Std. Deviation & N \\
\hline $\mathrm{Ba}$ & 1166.9000 & 773.32506 & 10 \\
$\mathrm{Cu}$ & 29.6100 & 22.82647 & 10 \\
$\mathrm{~Pb}$ & 33.7800 & 16.92045 & 10 \\
$\mathrm{Zn}$ & 130.7000 & 73.34098 & 10 \\
$\mathrm{Ag}$ & 0.0000 & 0.00000 & 10 \\
$\mathrm{Co}$ & 24.5100 & 27.83285 & 10 \\
$\mathrm{Mn}$ & 1065.2000 & 942.80065 & 10 \\
$\mathrm{Fe}$ & 171.2000 & 403.95456 & 10 \\
$\mathrm{AS}$ & 24.5100 & 27.83285 & 10 \\
$\mathrm{~V}$ & 43.5000 & 48.63069 & 10 \\
$\mathrm{Cr}$ & 171.2000 & 403.95456 & 10 \\
\hline
\end{tabular}

chemical weathering. It is a comparison between a mineral or a chemical compound that is relatively stable with one that is readily removed by weathering. The ratio of quartz to feldspar is a widely used index. The purpose of performing weathering index characteristics of the selected rock samples at Erinjiyan and its environs is to verify whether the rocks samples are suitable for geochemical exploration. The weathering indices parameters include Chemical index of Alteration (CIA), the Plagioclase Index of Alteration (PIA) and the Chemical Index of Weathering (CIW) data are presented in Table 6.

$\mathrm{ClA}=\left(\mathrm{Al}_{2} \mathrm{O}_{3} /\left(\mathrm{Al}_{2} \mathrm{O}_{3}+\mathrm{CaO}+\mathrm{Na}_{2} \mathrm{O}+\mathrm{K}_{2} \mathrm{O}\right) \times 100\right.$ (Nesbit and Young, 1982)

$$
\begin{aligned}
& \mathrm{PIA}=\left(\left\{\mathrm{Al}_{2} \mathrm{O}_{3}-\mathrm{K}_{2} \mathrm{O}\right) /\left(\left\{\mathrm{Al}_{2} \mathrm{O}_{3}-\mathrm{K}_{2} \mathrm{O}\right)+\mathrm{Na}_{2} \mathrm{O}\right)\right) \times 100 \\
& \mathrm{CIW}=\left\{\left\{\mathrm{Al}_{2} \mathrm{O}_{3} /\left(\mathrm{Al}_{2} \mathrm{O}_{3}+\mathrm{CaO}^{*}+\mathrm{Na}_{2} \mathrm{O}\right\}\right\} \times 100\right.
\end{aligned}
$$

$\mathrm{CIW}=\left(\mathrm{Al}_{2} \mathrm{O}_{3} /\left(\mathrm{Al}_{2} \mathrm{O}_{3}+\mathrm{Na}_{2} \mathrm{O}\right)\right) \times 100$

In the above equations the major oxides are expressed in molar proportions and $\mathrm{CaO}^{*}$ is the content of $\mathrm{CaO}$ incorporated in silicate fraction. McLennan (1993) proposed an indirect method for quantifying $\mathrm{CaO}$ content of silicate fraction assuming reasonable values of $\mathrm{Ca} / \mathrm{Na}$ ratios of silicate material. Procedure for quantification of $\mathrm{CaO}$ content $\left(\mathrm{CaO}^{*}\right)$ of silicate fraction involves subtraction of molar proportion of $\mathrm{P}_{2} \mathrm{O}_{5}$ from the molar proportion of total $\mathrm{CaO}$. After subtraction, if the "remaining number of moles" is found to be less than the molar proportion of $\mathrm{Na}_{2} \mathrm{O}$, then the "remaining number of moles" is considered as the molar proportion of $\mathrm{CaO}$ of silicate fraction. If the "remaining number of moles" is greater than the molar proportion of $\mathrm{Na}_{2} \mathrm{O}$, then the molar proportion of $\mathrm{Na}_{2} \mathrm{O}$ is considered as the molar proportion of $\mathrm{CaO}$ of silicate fraction $\left(\mathrm{CaO}^{*}\right)$. From the analysis and calcula- 
Table 5. Correlation showing inter relationship between metals.

\begin{tabular}{l|ccccccccccc}
\hline Elements & $\mathbf{B a}$ & $\mathbf{C u}$ & $\mathbf{P b}$ & $\mathbf{Z n}$ & $\mathbf{A g}$ & $\mathbf{C o}$ & $\mathbf{M n}$ & $\mathbf{F e}$ & $\mathbf{A S}$ & $\mathbf{V}$ & $\mathbf{C r}$ \\
\hline $\mathbf{B a}$ & 1 & 0.455 & 0.566 & $0.706^{*}$ & 0 & -0.212 & 0.296 & -0.512 & -0.212 & -0.030 & -0.512 \\
$\mathbf{C u}$ & 0.455 & 1 & 0.428 & $0.877^{* *}$ & 0 & 0.256 & 0.581 & -0.283 & 0.256 & 0.461 & -0.283 \\
$\mathbf{P b}$ & 0.566 & 0.428 & 1 & 0.541 & 0 & 0.010 & 0.611 & -0.620 & 0.010 & 0.408 & -0.620 \\
$\mathbf{Z n}$ & $0.706^{*}$ & $0.877^{* *}$ & 0.541 & 1 & 0 & 0.350 & 0.627 & -0.185 & 0.350 & 0.456 & -0.185 \\
$\mathbf{A g}$ & 0 & 0 & 0 & 0 & 0 & 0 & 0 & 0 & 0 & 0 & 0 \\
$\mathbf{C o}$ & -0.212 & 0.256 & 0.010 & 0.350 & 0 & 1 & $0.660^{*}$ & 0.626 & $1.000^{* *}$ & $0.752^{*}$ & 0.626 \\
$\mathbf{M n}$ & 0.296 & 0.581 & 0.611 & 0.627 & 0 & $0.660^{*}$ & 1 & -0.155 & $0.660^{*}$ & $0.872^{* *}$ & -0.155 \\
$\mathbf{F e}$ & -0.512 & -0.283 & -0.620 & -0.185 & 0 & 0.626 & -0.155 & 1 & 0.626 & 0.033 & $1.000^{* *}$ \\
$\mathbf{A S}$ & -0.212 & 0.256 & 0.010 & 0.350 & 0 & $1.000^{* *}$ & $0.660^{*}$ & 0.626 & 1 & $0.752^{*}$ & 0.626 \\
$\mathbf{V}$ & -0.030 & 0.461 & 0.408 & 0.456 & 0 & $0.752^{*}$ & $0.872^{* *}$ & 0.033 & $0.752^{*}$ & 1 & 0.033 \\
$\mathbf{C r}$ & -0.512 & -0.283 & -0.620 & -0.185 & 0 & 0.626 & -0.155 & $1.000^{* *}$ & 0.626 & 0.033 & 1 \\
\hline
\end{tabular}

Table 6. Weathering indices (\%).

\begin{tabular}{lccc}
\hline Sample ID & CIA & PIA & CIW \\
\hline Ikogosi Road L5 & 44.65 & 41.06 & 55.85 \\
Iwaro North L7 & 54.85 & 58.92 & 71.06 \\
Oke-Agbara L10 & 58.94 & 60.68 & 64.17 \\
Baptist L16 & 53.91 & 58.82 & 74.70 \\
Aafin L17 & 55.62 & 58.50 & 66.97 \\
Ago-Olopa L23 & 57.14 & 62.01 & 71.67 \\
Community- Court L24 & 28.98 & -72.02 & 49.46 \\
Aramoko Road L28 & 64.86 & 69.49 & 73.60 \\
Efon L30 & 53.99 & 55.12 & 60.71 \\
St.Paul 33 & 58.61 & 62.15 & 68.60 \\
\hline
\end{tabular}

tions, it was discovered that the $\mathrm{CIA}$ ranges from 28.98 to $64.8 \%$, the PIA ranges from -72 to $69.49 \%$ while the CIW ranges from 49.46 to $74.70 \%$ (Table 6 ). This means that the rock samples selected fell within the range of freshly to moderately weathered samples. Therefore, the rocks are suitable for mineral exploration.

\section{Conclusion}

The results of the geological and geochemical studies of the bedrocks in Erijiyan area, has been presented. However, field observations revealed that the dominant lithology in the studied area are the quartzites which are ferruginous by virtue of their chemical composition. Other rocks included the pegmatites which are the major intrusives within the quartzites and the quartz schists. The quartzites in the studied area have undergone some deformational episodes which are evident in their joint pattern.

The NE-SW orientation of these joints are believed to be relics of the Pan-African orogenic events. The quartz schist and the pegmatites are enriched with minerals such as $\mathrm{Cu}, \mathrm{Zn}, \mathrm{Cr}$ and $\mathrm{Fe}$. One interesting feature here is that the quartz schists show similar attributes with that of Ajindo (Okemesi) in terms of gold showings by nature of its chemical composition and its pathfinder elements.

The study area is also suspected of copper or sulphide enrichment especially in the quartz schists. Therefore, detailed geochemical investigation is recommended to unravel the geochemistry of the pegmatites in the studied area.

\section{CONFLICT OF INTEREST}

The authors declare that they have no conflict of interest.

\section{REFERENCES}

Agterberg, F. P. (1974). Automatic contouring of geological maps to detect target areas for mineral exploration. Journal of the International Association for Mathematical Geology, 6(4), 373395.

Akanmu, T., Oshin, O. O., Ayodele, O. S. (2019). Mineralogical Characterization of theGold-bearing rocks Around Okemesiljero Area, Southwestern Nigeria. Global Scientific Journals, 
7(1), 34-76.

Ajibade, A. C. (1988). Structural and tectonic evolution of the Nigeria basement with special reference to $\mathrm{N} \mathrm{W}$ Nigeria. International Conference Proterozoic Geology and tectonics of high- grade terrain, Ife, Nigeria.

Ajibade, A. C., \& Wright, J. B. (1989). The Togo-Benin-Nigeria Shield: evidence of crustal aggregation in the Pan-African belt. Tectonophysics, 165(1-4), 125-129.

Ayodele, O. S., Oshin, O. O., \& Awokunmi, E. E. (2017). Auriferous Showings in the Bedrocks and Stream Sediments of Okemesi-ljero Area, Southwestern Nigeria. American Journal of Earth Sciences, 4(2), 8-31.

Beus, A. A., \& Grigorian, S. V. (1977). Geochemical exploration methods for mineral deposits. Applied Publishing Limited. USA. 31-270.

Boyle, R. W., Tupper, W. M., Lynch, J., Friedrich, G., Ziauddin, M., Shafiqullah, C. M., \& Bygrave, K (1996). Geochemistry of $\mathrm{Pb}, \mathrm{Zn}, \mathrm{Cu}, \mathrm{As}, \mathrm{Sb}, \mathrm{Mo}, \mathrm{Sn}, \mathrm{W}, \mathrm{Ag}, \mathrm{Ni}, \mathrm{Co}, \mathrm{Cr}, \mathrm{Ba}$ and $\mathrm{M}$ in the waters and stream sediments of the Bathrust-TaquetRiver District, New Brunswich. GSC Paper. 41-65.

Brandon, M. T., Roden-Tice, M. K., \& Garver, J. I. (1998). Late Cenozoic exhumation of the Cascadianaccretionary wedge in the Olympic Mountains, northwest Washington State. Geological Society of America Bulletin, 110(8), 9851009.

Dada, S. S., and Rahaman, M. A. (1995): Archean-Lower Paleozoic Crustal evolution in Nigeria. African Geoscience Review, 2(19), 43-58.

England, P., \& Molnar, P. (1990). Surface uplift, uplift of rocks, and exhumation of rocks. Geology, 18(12), 1173-1177.

Feng, X., Wang, E., Ganne, J., Martin, R., \& Jessell, M. (2018). The exhumation along the Kenyase and Ketesso shear zones in the Sefwi terrane, West African Craton: a numerical study. Geosciences Journal, 1-18.

Feng, X., Amponsah, P. O., Martin, R., Ganne, J., \& Jessell, M. W. (2016). 3-D numerical modelling of the influence of preexisting faults and boundary conditions on the distribution of deformation: Example of North-Western Ghana. Precambrian Research, 274, 161-179.

Freeth, S. J., (1971). Geochemical and related studies of West African igneous and metamorphic rocks. Unpublished Ph.D thesis. University of Ibadan. 240p.

Ganne, J., Bachmann, O., Feng, X. (2018). Deep into magma plumbing systems: Interrogating the crystal cargo of volcanic deposits. Geology, 46(5), 415-418.

Ganne, J., Feng, X., Rey, P., \& De Andrade, V. (2016). Statistical petrology reveals a link between supercontinents cycle and mantle global climate. American Mineralogist, 101(12), 27682773.

Garba, I. (2003). Geochemical discrimination of newly discovered rare-metal bearing and barren pegmatites in the Pan-African $(600 \pm 150 \mathrm{Ma})$ basement of northern Nigeria. Applied Earth Science, 112(3), 287-292.
Grant, N. K. (1970). Geochronology of Precambrian basement rocks from Ibadan, Southwestern Nigeria. Earth and Planet Science letters, 10, 29-38.

Jones, H. A., \& Hockey, R. D., (1964). The geology of part of southwestern Nigeria. Geological Survey of Nigeria, Bulletin 31.

Kaufmann, O., \& Martin, T. (2008). 3D geological modelling from boreholes, cross-sections and geological maps, application over former natural gas storages in coal mines. Computers \& geosciences, 34(3), 278-290.

McCurry, P. (1973). Geology of degree sheet 21, Zana, Nigeria. Overseas Geology and Mineral Resources. No. 45, H.M.S.O. London.

McCurry, P. (1976). The geology of the Precambrian to Lower Paleozoic rocks of the northern Nigeria. In: Kogbe C. A. (ed) Geology of Nigeria, Elizabethan Publishing Company, Lagos, Pp. 67-99.

Odeyemi, I. B. (1972). Industrial Mineral Potentials of ljero Pegmatites in Ekiti State, World Applied Science Journal, 29(3), 415-420.

Oyawoye, M. O. (1972). The basement complex of Nigeria in Dessauvagie, T. F. J. and Whiteman A. J. W. (eds) University of Ibadan 1970, 66-102.

Rahaman, M. A. (1976). Review of the basement geology of southwestern Nigeria. In: Kogbe, C.A. (ed.) Geology of Nigeria. Elizabethan Publishing Co., Lagos, 41-58.

Rahaman, M. A. and Ocan, O. O. (1978). On relationships in the Precambrian migmatititic gneiss of Nigeria. Journal of Mining and Geology, 15, 23-32.

Rahaman, M. A. (1988). Recent advances in the Study of the basement complex of Nigeria. In: Precambrian Geology of Nigeria. Geological Survey of Nigeria, Pp. 11-43.

Russ, W., (1957). The geology of parts of the Niger, Zaria and Sokoto provinces with special reference to the occurrence of gold. Nigeria Geological Survey Bulletin, 27, 42p.

Turner, D. C. (1983). Upper Proterozoic schist belt in Nigeria sector of the Pan African province of West Africa. Precambrian Research. 21, 55-79.

Watts, D. W., \& Johnson, M. H. (2012). Geochemical mapping using stream sediments in west-central Nigeria. Implications for environmental studies and mineral exploration in West Africa. Applied Geochemistry, 27(6), 1035-1062.

Wright, J. S. (1976). Fracture systems in Nigeria and initiation of fracture zones in the South Atlantic. Tectonophysics, 34, 4347. 